\title{
Correlation between High-Resolution Computed Tomography Scan Findings and Histological Findings in Human Vestibular End Organs and Surgical Implications
}

\author{
Raquel Manrique-Huarte Cristina Zulueta-Santos Octavio Garaycochea \\ Marta Alvarez Linera-Alperi Manuel Manrique
}

Otorhinolaryngology Department, University of Navarra Clinic, Pamplona, Spain

\section{Keywords}

Vestibular system · Otolith organ · Inner ear radiology ·

Vestibule histology

\begin{abstract}
Background: Histological study of vestibular end organs has been challenging due to the difficulty in preserving their structures for histological analysis and due to their complex geometry. Recently, radiology advances have allowed to deepen the study of the membranous labyrinth. Summary: A review and analysis of surgical implications related to the anatomy of the vestibular end organ is performed. Radiological advances are key in the advancement of the knowledge of the anatomy and pathology of the vestibule. Thus, application of such knowledge in the development or improvement of surgical procedures may facilitate the development of novel techniques. Key Messages: During the last few decades, the knowledge of the anatomy of the auditory system through histology and radiology had improved. Technological advances in this field may lead to a better diagnosis and therapeutic approach of most common and important diseases affecting the inner ear.
\end{abstract}

(c) 2020 The Author(s)

Published by S. Karger AG, Basel

\section{KARGER}

E-Mail karger@karger.com www.karger.com/aud

\section{(C) 2020 The Author(s)}

Published by S. Karger AG, Basel

Karger

Open access

This article is licensed under the Creative Commons AttributionNonCommercial-NoDerivatives 4.0 International License (CC BY NC-ND) (http://www.karger.com/Services/OpenAccessLicense). Usage and distribution for commercial purposes as well as any distribution of modified material requires written permission.

\section{Introduction}

The 20th century was fundamental in attaining current knowledge cohesion regarding anatomy, histology and physiology of the inner ear. The Spanish scientists Santiago Ramón y Cajal (1852-1934) and Rafael Lorente de Nó (1902-1990) contributed to a better understanding of the microscopic anatomy and histology of the inner ear and its innervation. Santiago Ramón y Cajal described the dendritic cone in addition to his research on nervous systems [Cajal, 1899 and 1904], his reflections on degeneration and regeneration, and his theories about function, development and plasticity. The circuitry underlying the vestibulo-ocular reflex (VOR) is the best characterized vestibular-driven pathway. Lorente de Nó [1933] demonstrated the existence of a three-neuronal arc that represents the most direct pathway between vestibular afferents and eye muscles. To date, visualization of the membranous labyrinth within the vestibule has been difficult given the limited access to the temporal bone. Although histological analysis [Handzel et al., 2006] has shed some light, preservation and processing of such structures is a challenge. Besides, the peripheral vestibular system has a complex geometry that does not permit equally advanta-

Raquel Manrique-Huarte

Otorhinolaryngology Department, University of Navarra Clinic Spain-Pio XII, 36

ES-31008 Pamplona (Spain)

E-Mail rmanrique@unav.es 
geous visualization of the five end organs in a single plane of section [Rauch, 2001]. Recently, radiology advances, such as three-dimensional (3D) assessment based on micro-computed tomography [Mukherjee et al., 2019], allow to deepen the study of the membranous labyrinth.

Over the last 10 years, progress in developing vestibular prostheses has been made [Boutros et al., 2019; Golub et al., 2014; Pelizzone et al., 2014]. So far, in nonhuman primates, electrical stimulation of vestibular afferent neurons in order to partially restore semicircular canal sensation of head rotation and the stabilizing reflexes that sensation supports has potential to effectively treat individuals disabled by bilateral vestibular hypofunction [Boutros et al., 2019]. In 7 patients with bilateral vestibular loss, that artificial restoration of the VOR is possible via electrical stimulation of the vestibular nerve branches [Pelizzone et al., 2014]. In a single subject with advanced Ménière's disease (MD), prosthesis implantation of the semicircular canals is technically feasible and electrical stimulation resulted in canal-specific eye movements [Golub et al., 2014].

For this, it is necessary for the oto-surgeon to be acquainted with the complex inner ear anatomy. Inner ear surgery requires more detailed information about the topographic anatomy and variations. So far, scarce studies showing detailed information on membranous labyrinth anatomy have been published.

The aim of this study is to review the anatomy of the membranous labyrinth within the vestibule on healthy subjects and patients with profound sensorineural hearing loss, so as to offer greater accuracy to the oto-surgeon during vestibular prostheses surgery.

\section{Materials and Methods}

A literature search was performed in April 2019 to identify original articles involving a histological or radiological description of the anatomy of the vestibular end organs and its possible implications related to otological surgical procedures. The search strategy was based on the use of Medical Subject Headings (MeSH). The MeSH terms used for the research were: labyrinth vestibular, otolithic membrane, ear vestibule, inner ear, saccule and utricle AND radiology, anatomy and histology. Studies with models involving animals were also included. Articles were selected in any language, without time restriction. The main databases consulted were the following: SciELO (Scientific Electronic Library Online), PubMed (National Library of Medicine and National Institute of Health), and Google scholar. The search was performed by two independent reviewers. Moreover, when the references of the included studies or recent reviews were searched, additional original articles were found and taken into account for this study. Only articles with descriptive results of anatomical histology and radio-

Vestibular End Organ: Radiological and Histological Findings logical findings of the temporal bone and those related to the surgical outcomes from otological surgeries (stapedectomy, cochlear implant) were included. Articles with exclusively functional data were excluded. After performing the search and selection of potentially relevant studies and having verified that each article was considered only once, 11 studies were included in the qualitative synthesis.

\section{Results}

A total of 13 articles were used for this review of the literature. We found 8 original articles related to radiological findings, 5 to histological findings and 1 focusing on the repercussion of the otosclerosis surgical procedure. The main findings of these articles are summarized below in the following categories.

\section{Radiological Findings}

Results are summarized in Table 1. Different radiological techniques have been performed to analyze the vestibular end organ. Mukherjee et al. [2011] described a $3 \mathrm{D}$ reconstruction of vestibular structures using a $3 \mathrm{D}$ computed tomography with an average scan time of $8 \mathrm{~h}$ and scan width of $23.4 \mu \mathrm{m}$ with measurements in vertical plane. This technique was described so as to provide distances from the utricle and saccule to the footplate in 1 guinea pig and 17 cadaveric human temporal bones without abnormalities. Membrana limitans (ML) is reported to structurally separate parts of the membranous labyrinth. The authors described that in $50 \%$ of the cases the ML ran from the utricular macula directly to the stapes footplate and was likely to occur bilaterally. Attachments were found to the posterior one-third of the stapes footplate only. Uzun-Coruhlu et al. [2007] studied human and guinea pig specimens to clarify the mechanism of anatomical attachment and physical support of the saccular and utricular macula employing a Skyscan 1172 high-resolution desktop X-ray micro-tomography system and latterly using the data and volume rendering algorithm to reconstruct each inner ear in full 3D context. The authors concluded that the saccular maculae are closely attached to the curved bony surface of the temporal bone as traditionally believed, but the utricular macula is attached to the temporal bone only at the anterior region of the macula. Similar findings are described by Curthoys et al. [2009], who studied both guinea pigs and temporal bones using a nondestructive technique - high-resolution X-ray micro-tomography of fixed temporal bones stained by osmium tetroxide - to show the spatial orientation and configuration of the membranous labyrinth structures. 
Table 1. Vestibular end organ radiological findings are summarized

\begin{tabular}{|c|c|c|}
\hline Author & Patients and methodology & Radiology outcomes \\
\hline $\begin{array}{l}\text { Mukherjee et al. } \\
\text { [2019] }\end{array}$ & $\begin{array}{l}\text { One guinea pig and } 17 \text { cadaveric } \\
\text { human temporal bones without } \\
\text { abnormalities }\end{array}$ & $\begin{array}{l}\text { Membrana limitans attachments from utricular } \\
\text { macula to stapes footplate (posterior one-third, } \\
\text { more likely to occur bilaterally) }\end{array}$ \\
\hline Conte et al. [2018] & $\begin{array}{l}\text { Post-contrast 3D-FLAIR sequence } \\
\text { in } 22 \text { consecutive patients with uni- } \\
\text { lateral sudden hearing loss }\end{array}$ & $\begin{array}{l}\text { On the sagittal medial plane, the saccule was de- } \\
\text { tectable in } 15 / 22(68 \%) \text { ears, having a club shape } \\
\text { with the long axis oriented cranio-caudally; in } \\
7 / 22(32 \%) \text { ears, the saccule presented an oval/ } \\
\text { round shape that appeared more conspicuously } \\
\text { on the axial intermediate plane; the ELS occupied } \\
\text { the half superior portion of the vestibule in } 22 / 22 \\
\text { ears, never contacting the round and oval } \\
\text { windows }\end{array}$ \\
\hline $\begin{array}{l}\text { Yamane et al. } \\
\text { [2015] }\end{array}$ & $\begin{array}{l}\text { 3D cone beam computed tomogra- } \\
\text { phy in } 13 \text { healthy volunteers and } 25 \\
\text { MD patients }\end{array}$ & $\begin{array}{l}\text { Ductus reuniens is wider, more irregular and } \\
\text { condensed among MD patients than healthy } \\
\text { subjects }\end{array}$ \\
\hline $\begin{array}{l}\text { Uzun-Coruhlu } \\
\text { et al. [2007] }\end{array}$ & $\begin{array}{l}\mathrm{X} \text {-ray microtomography in human } \\
\text { and guinea pig specimens }\end{array}$ & $\begin{array}{l}\text { Utricular macula is attached to the temporal bone } \\
\text { only at the anterior region of the macula and } \\
\text { saccular maculae is closely attached to the curved } \\
\text { bony surface }\end{array}$ \\
\hline Inui et al. [2016] & $\begin{array}{l}\text { 3D images of the inner ear fluid } \\
\text { space and the ELS to obtain quanti- } \\
\text { tative volumetric measurements of } \\
\text { inner ear }\end{array}$ & $\begin{array}{l}\text { Mean ELS/TFS ratio in the cochlea was } 8.8 \% \text {, and } \\
\text { that in the vestibule was } 16.2 \%\end{array}$ \\
\hline $\begin{array}{l}\text { Monsanto } \\
\text { et al. [2017] }\end{array}$ & $\begin{array}{l}\text { 3D model and volume of the endo- } \\
\text { lymph drainage system in temporal } \\
\text { bones of specimens with MD, EH } \\
\text { without vestibular symptoms and } \\
\text { specimens with nondiseased }\end{array}$ & $\begin{array}{l}\text { Vestibular aqueduct and of the endolymphatic } \\
\text { sinus, duct, and intratemporal endolymphatic sac } \\
\text { was significantly lower in the MD; the external } \\
\text { aperture of the vestibular aqueduct was also } \\
\text { smaller in the MD group and the Bast's valve was } \\
\text { open only in some specimens in the MD group }\end{array}$ \\
\hline $\begin{array}{l}\text { Curthoys et al. } \\
\text { [2009] }\end{array}$ & $\begin{array}{l}\text { High-resolution X-ray microtomog- } \\
\text { raphy of the membranous labyrinth } \\
\text { of fixed guinea pig and human } \\
\text { inner ears }\end{array}$ & $\begin{array}{l}\text { The saccular macula is closely attached to the } \\
\text { curved medial wall of the temporal bone; utricu- } \\
\text { lar macula is attached to the temporal bone only } \\
\text { at the anterior region of the macula }\end{array}$ \\
\hline Lane et al. [2008] & $\begin{array}{l}\text { 3-T MRI of the temporal bone using } \\
\text { the VFA FSE technique in healthy } \\
\text { volunteers }\end{array}$ & $\begin{array}{l}\text { It is possible to visualize the neurosensory epithe- } \\
\text { lium and different portions of the membranous } \\
\text { labyrinth by using the latest FSE techniques }\end{array}$ \\
\hline
\end{tabular}

ELS, endolymphatic space; TFS, total fluid space; MD, Ménière's disease; EH, endolymphatic hydrops; VFA, variable flip-angle; FSE, fast spin-echo.

Lane et al. [2008] reviewed the anatomy of the inner ear with the 3-T magnetic resonance imaging (MRI) 3D variable flip-angle fast spin-echo technique to demonstrate some of the more prominent neurosensory components of the membranous labyrinth, such as the semicircular canal ampullae and both maculae. Yamane et al. [2014] analyzed affected ears of patients with MD using a 3D CT (Accuitomo cone beam CT scanner $-80 \mathrm{kV}, 6 \mathrm{~mA}$; voxel size $0.125 \times 0.125 \times 0.125 \mathrm{~mm}$, and slice thickness $0.5 \mathrm{~mm}$ ) and obtained reconstructed $3 \mathrm{D}$ images using a rendering software (IVIEW). Specifically, they studied the membranous labyrinth for the visual assessment of the bony grooves of the ductus reuniens, saccular duct, and endolymphatic sinus. The authors described morphological malformations in the affected ears supporting the hypothesis proposed earlier that ductus reuniens 
Table 2. Summarizes histological findings

\begin{tabular}{|c|c|c|}
\hline Author & Patients and methodology & Histological outcomes \\
\hline Rauch [2001] & $\begin{array}{l}\text { Histological outcomes of human } \\
\text { temporal bones }\end{array}$ & $\begin{array}{l}\text { Ménière's disease: idiopathic endolymphatic hydrops, } \\
\text { especially of the cochlear duct and saccule } \\
\text { Viral labyrinthitis: cochleosaccular degeneration, } \\
\text { endolymphatic hydrops, atrophy and fibro-osseous } \\
\text { proliferation } \\
\text { Vestibular neuronitis: segmental loss of isolated } \\
\text { branches of the vestibular nerve } \\
\text { Vestibular ototoxicity: significant loss of type I and } \\
\text { type II hair cells in all five vestibular sense organs } \\
\text { and/or mild intercellular edema }\end{array}$ \\
\hline $\begin{array}{l}\text { Pauw et al. } \\
\text { [1991] }\end{array}$ & $\begin{array}{l}\text { Histologic outcomes of } 10 \text { normal } \\
\text { temporal bones and } 11 \text { from } \\
\text { patients with otosclerosis }\end{array}$ & $\begin{array}{l}\text { A detail description of measures and volumes of } \\
\text { saccule and utricle is performed; no significant } \\
\text { differences for the mean values obtained in normal } \\
\text { and otosclerotic temporal bones }\end{array}$ \\
\hline $\begin{array}{l}\text { Rosenhall } \\
{[1972]}\end{array}$ & $\begin{array}{l}\text { Histologic outcomes of } 31 \text { human } \\
\text { temporal bones without abnormal- } \\
\text { ities }\end{array}$ & $\begin{array}{l}\text { Histology and ultrastructure of human vestibular } \\
\text { end organs is similar to that found in other mammals }\end{array}$ \\
\hline $\begin{array}{l}\text { Handzel et al. } \\
{[2006]}\end{array}$ & $\begin{array}{l}\text { Histologic outcomes of } 9 \text { temporal } \\
\text { bones after cochlear implantation }\end{array}$ & $\begin{array}{l}\text { Cochlear implantation causes endolymphatic hy- } \\
\text { drops, saccule collapse and less frequently the utricle }\end{array}$ \\
\hline
\end{tabular}

blockade is a result of the dislodgement of saccular otoconia.

The recent development and progress of MRI techniques has enabled the visualization of endolymphatic hydrops (EH) in living human subjects using a 3-T scanner and gadolinium-based contrast agent via intravenous or intratympanic administration. Conte et al. [2018] described the in vivo anatomy of the vestibular system in 22 consecutive patients with unilateral sudden hearing loss. In this study, all patients were imaged on a 3-T Philips Achieva ${ }^{\circledR}$ Scanner using a 32-channel head coil. Sequences were performed for whole brain evaluation (axial diffusion-weighted sequence and 3D FLAIR) and some other specific sequences for temporal bone assessment. A contrast agent (Gadoteridol, Prohance ${ }^{\circledR}$; Bracco Diagnostic Inc.) was administered intravenously at a dose of $0.2 \mathrm{mmol} / \mathrm{kg}$. After $4.5 \mathrm{~h}$, the 3D FLAIR sequence was acquired. They described the SCC ampulla combined with the utricle in 22/22 ears. The saccule was detectable in 15/22 (68\%) ears, having a club shape with the long axis oriented cranio-caudally. Endolymphatic space (ELS) occupied the half-superior portion of the vestibule in 22/22 ears, never contacting the round and oval windows. Some attempts to measure the quantitative volume of the ELS have been made [Inui et al., 2016]. Although the spatial resolution of the delayed post-contrast 3D FLAIR se- quence is consistent among suites, it is not sufficient to perform a reliable segmentation of the ELS to provide its normative volumetric data [Conte et al., 2018]. Moreover, the conspicuity of the ELS on FLAIR imaging depends on the inversion time chosen [Lane et al., 2008]. Another limitation of MRI is the difficulty to separately visualize the ELS within de SCC ampullae, due to its small size [Inui et al., 2016].

In order to measure the volume of the endolymph drainage system in temporal bones with $\mathrm{MD}, \mathrm{EH}$ and nondiseased specimens, Monsanto et al. [2017] generated 3D models of the vestibular aqueduct, endolymphatic sinus and duct, and intratemporal portion of the endolymphatic sac and calculated the volume of those structures. Temporal bones were scanned with a high-resolution scanner (PathScan Enabler IV, Meyer Instruments, Houston, TX, USA) and Amira software (Amira 3D Software for Life Sciences, FEI, Hillsboro, OR, USA) was used to generate a 3D reconstruction model. The authors concluded that the volume of the vestibular aqueduct and of the endolymphatic sinus, duct, and intratemporal endolymphatic sac was significantly lower in the MD group than in the EH group $(p<0.05)$. The external aperture of the vestibular aqueduct was also smaller in the $\mathrm{MD}$ group and the Bast's valve was open only in some specimens in the MD group. 


\section{Histological Findings}

The results obtained from each article are summarized (Table 2), being previously classified in 3 different categories according to the kind of subject studied

\section{Nondiseased Temporal Bones}

Pauw et al. [1991], after analyzing the histologic outcomes of 10 normal temporal bones and 11 from patients with otosclerosis, came to the conclusion that measurements taken from the medial surface of the stapedial footplate to the vestibular end organs and cochlear duct show no significant differences in the mean values obtained in normal and otosclerotic temporal bones. The mean distances to the utricle ranged from 1.9 to $2.4 \mathrm{~mm}$, and those to the saccule from 1.7 to $2.1 \mathrm{~mm}$. The minimal distance to the utricle was measured from the posterior $(0.58 \mathrm{~mm})$ and superior $(0.62 \mathrm{~mm})$ borders of the stapedial footplate. The minimal distances to the saccule were measured from the anterior $(0.76,0.86$, and $1.00 \mathrm{~mm})$ border of the stapedial footplate. All other measurements were of more than $1 \mathrm{~mm}$. The shortest distance between the cochlear duct and the inferior border of the footplate was $0.2 \mathrm{~mm}$. By studying the sensory regions of 31 human temporal bones without abnormalities using the surface specimen technique, Rosenhall [1972] demonstrated that the dimensions can be measured easily and directly and hair cell populations can be estimated accurately. The histology and ultrastructure of human vestibular end organs is similar to that found in other mammals. The macula utriculi has an average surface area of $4.29 \mathrm{~mm}^{2}$ and the macula sacculi of $2.44 \mathrm{~mm}^{2}$.

\section{Diseased Temporal Bones}

Rauch et al. [2001] obtained histological data from 119 patients with MD, 32 with benign paroxysmal positional vertigo, 299 with labyrinthitis, unspecified, 20 with vestibular neuritis, and 152 with aminoglycoside and loop diuretics ototoxicity. A description of each pathology was then executed. In MD, the histopathologic finding was idiopathic EH, especially of the cochlear duct and saccule. In early stages of this disease, proliferation of fibrous tissue causing bands and adhesions between the dilated membranous labyrinth and walls of the temporal bone can be found. In advanced disease, however, it is possible to detect degenerative changes that include hair cell loss, atrophy of supporting cells, tectorial membrane, and cristae, as well as a significant reduction in the number of afferent nerve endings and afferent synapses at the base of inner and outer hair cells of the cochlea, and selective loss of type II hair cells and Scarpa's ganglion cells. In benign paroxysmal positional vertigo, canalithiasis is unlikely to be present in postmortem bones due to decalcification during histologic processing; that is why it was difficult to correctly analyze the results obtained under this pathological condition. Viral labyrinthitis shows cochleosaccular degeneration, EH and varying degrees of atrophy and fibrosis or fibro-osseous proliferation in the sensory epithelia and supporting cells. Moreover, loss of sensory epithelia is accompanied by severe neuronal degeneration. Vestibular neuronitis does not affect the cochlea and vascular structures appear normal, but it causes segmental loss of isolated branches of the vestibular nerve peripheral to Scarpa's ganglion. Vestibular ototoxicity was analyzed for two groups of drugs. On the one hand, loop diuretics such as furosemide or ethacrynic acid showed mild intercellular edema of the sensory epithelium and severe intercellular edema in the dark cell area of the vestibular labyrinth and stria vascularis of the cochlea. On the other hand, aminoglycosides such as streptomycin and kanamycin cause significant loss of type I and type II hair cells in all 5 vestibular sense organs, with greater loss of type I than type II hair cells in the cristae but not the maculae. Neomycin, however, caused profound loss of cochlear hair cells but did not affect vestibular hair cells. Handzel et al. [2006] described the histologic outcomes of 9 temporal bones after cochlear implantation, showing that cochlear implantation does not cause deafferentation of the peripheral vestibular system. In 59\% of the implanted bones, the cochlea was hydropic, and in the majority of these bones, the saccule was collapsed. Cochlear hydrops accompanied by saccular collapse is common and may cause attacks of vertigo of delayed onset, similar to $\mathrm{MD}$ as previously reported in several clinical series.

\section{Discussion}

The anatomy of the auditory system and the otopathology function are well established and have been described in depth. Most otopathology specialists know the study protocols of the auditory system. However, and though many advances have been made, there are still not as many exhaustive studies considering the vestibular system. There is a need to improve vestibular function testing and standardization in patients who report vestibular dysfunction. This lack of in-depth knowledge is, on the one hand, due to the complexity of the physiology and great variety of vestibular tests and on the other hand, to the complex anatomic geometry of the peripheral vestibular system. The cochlea's regular anatomy enables a simpler histological analysis, whereas the vestibule is formed by 5 end or- 
gans (the 3 semicircular canals, the utricle and the saccule) arranged in different planes of space [Rauch, 2001]. This affects not only the study of vestibular pathology, but also its treatment, which has remained practically unchanged for decades with destructive procedures (intratympanic gentamicin, labyrinthectomy and vestibular nerve section) and very few curative options [Golub et al., 2014].

A thorough knowledge of vestibular morphology is essential for understanding the function of the vestibular apparatus. Displacements and linear accelerations of the head are detected by the two otolith organs: the sacculus and the utricle. Previous histologic studies have made a fine description of these structures [Rosenhall, 1972] by studying 31 inner ears from infants and adults. These organs contain a sensory epithelium, the macula, which consists of hair cells and associated supporting cells. Overlying these cells is the otolithic membrane, where the otoconia are embedded. The saccular macula is oriented vertically, so this organ detects linear accelerations and head tilts in the vertical plane; and the utricular macula is oriented horizontally, thus detects linear accelerations and head tilts in the horizontal plane. These studies concluded that the average surface area of the macula utriculi was $4.29 \mathrm{~mm}^{2}$. Its length was about $2.8 \mathrm{~mm}$ and its maximal width about $2.2 \mathrm{~mm}$. Both utricle and saccule have a line called the striola, which divides the hair cells into two populations with opposing polarities. The average surface of the striola in the macula utriculi was $0.37 \mathrm{~mm}^{2}$, which is $8.6 \%$ of the total macular surface area, and the average total hair cell number of the macula utriculi was 33,100 cells. Regarding the macula sacculi, the average surface area was $2.44 \mathrm{~mm}^{2}$, and the average surface of the striola was $0.26 \mathrm{~mm}^{2}$. The total hair cell population was 18,800 cells. Merchant [1999] validated a quantitative method that enabled differentiation of hair cells from supporting cells and type I from type II hair cells based on morphologic criteria. This method permitted the creation of a database of hair cell counts and Scarpa's ganglion neuronal counts by age in the normal population which may be compared to populations with inner ear diseases such as $\mathrm{MD}$, where selective loss of type II hair cells and Scarpa's ganglion cells are seen [Schuknecht, 1993]. However, application of the microdissection technique and the unbiased stereologic technique allows a more reliable and accurate estimation [Ishiyama et al., 2004].

Histological studies have revealed valuable information, although their great limitation is that they do not allow us to study the anatomy of the inner ear in vivo. A histologic study that measured the distance between central areas of the medial surface of the stapes footplate to

Vestibular End Organ: Radiological and Histological Findings the utricle, the saccule, and the cochlear duct in 10 normal and 11 osteosclerotic temporal bones concluded that the safest place for a stapedotomy opening is in the central and inferior-central thirds of the footplate [Pauw et al., 1991]. Recently, radiology advances have allowed to deepen the knowledge and understanding of the anatomy of the membranous labyrinth. For instance, Ash et al. [2010] measured utricular macula dimension in 101 cases with 3-T MRI. The results of the study show that the average anteroposterior length is $1.68 \mathrm{~mm}$, transverse $1.51 \mathrm{~mm}$ and craniocaudal $1.02 \mathrm{~mm}$. Investigators from an Australian study group [Uzun-Corulu et al., 2007; Mukherjee et al., 2011, 2019] have reported a detailed 3D study of the vestibular end organs and their relation to the stapes footplate using a micro-CT scan. They have demonstrated the existence of a rich fibrillary network of tissue called the periotic connective tissue which supports the perilymphatic space and holds the vestibular end organs. Previous histological studies [Pauw et al., 1991] already reported the relations between the footplate and the utricle and saccule, concluding that the safest place for a stapedotomy opening is in the central and inferior-central thirds of the footplate. However, these more recent investigations have demonstrated attachments between the posterior third and less frequently the middle third of the footplate and the utricle in some patients through the so-called ML. This may have serious implications in surgical interventions and may be one of the causes why, although rarely, stapes surgery can lead to vestibular symptoms. These 3D microCT scan tools allow an anatomical assessment of the inner ear and may lead to future innovations.

As seen, application of imaging techniques in the study of the inner ear, and more specifically, of the vestibule, is evolving. However, the great advantage of imaging studies is that they allow us to study patients in vivo, informing about a specific disease (for diagnosis, for example) or about a preoperative situation. For instance, it is applied to detect or diagnose MD: MRI using local or systemic gadolinium contrast enhancement via the inner ear [Nakashima et al., 2007], or less commonly known, 3D cone beam CT (3DCT) [Yamane et al., 2014]. Regarding MRI, we are able to visualize EH in living patients with MD, as described by Nakashima et al. [2007]. EH has also been attributed to patients with vestibular migraine or low-frequency hearing loss. Delayed post-contrast 3D-FLAIR imaging is a valid tool to explore the in vivo anatomy of the vestibular ELS and to highlight its variability in normal ears [Conte et al., 2018]. Regarding the 3DCT, Yamane's study included 25 definite MD patients diagnosed according to the AAO-HNS guidelines, and 26 ears of healthy controls. They found significant dif- 
ferences between the ductus reuniens (between the vestibular cecum of the cochlea and saccule) in the MD ears and in healthy ears. The MD ears had a wide, irregular and condensed ductus reuniens whereas those of the healthy ears were narrow. This study group [Yamane et al., 2015] also found differences in the vestibular aqueduct using the 3DCT, which was obliterated in MD patients. These findings shed some light on the clinical evaluation of $\mathrm{MD}$ patients with a simple radiologic tool, without requiring morphologic measurements.

Vestibular end organ pathological findings among patients with vestibular disease show changes from healthy subjects' anatomy. In $\mathrm{MD}, \mathrm{EH}$ in the cochlear duct and saccule has been described histologically [Rauch, 2001] and radiologically [Nakashima et al., 2007]. Besides, other radiological findings show a wider, irregular and condensed ductus reuniens as well as an obliteration of the vestibular aqueduct [Yamane et al., 2014, 2015]. Such findings may be related to anatomic findings published by Monsanto et al. [2017] that suggest that differences in volume of the endolymph drainage system could correlate with the reason that some patients with hydrops develop clinical symptoms, whereas others do not.

These advances in the knowledge of the anatomy and functioning of the vestibular organ is of utmost importance, especially for surgeons who perform invasive techniques of the inner ear, such as the aforementioned stapes surgery or cochlear implants. Regarding otosclerosis surgery, special anatomical considerations must be taken into account and may be noticed thanks to imaging techniques. For example, the presence of a persistent stapedial artery may be associated with carotid artery aberrations and surgery can involve risks for facial palsy. Also, the round window may have otosclerosis lesions; facial nerve dehiscence is common and must be recognized, and the stapes anatomy is highly variable: the crura can be long or short, and the stapedial tendon can attach to different parts of the stapes [Rask-Andersen et al., 2018]. The insertion of an electrode into the cochlea has well-known consequences in this organ, but does it alter the vestibular end organs? Reports on patients who have received a cochlear implant and have vestibular symptoms or show abnormal vestibular tests are variable. Possible causes for vestibular symptoms after cochlear implantation may include direct surgical trauma or unintentional electrical stimulation of the vestibular system. A histologic study [Handzel et al., 2006] analyzed 9 temporal bones belonging to patients with cochlear implants and revealed that cochlear implantation may cause $\mathrm{EH}$ in the cochlea but also collapse of the saccule, and less frequently of the utricle. In this study, inves- tigators did not see any direct trauma in the vestibular end organs or loss of Scarpa's ganglion or hair cell counts, which may be associated with the actual minimally traumatic cochlear implant surgery techniques. However, dizziness after cochlear implantation may be due to the obstruction of the endolymphatic flow in the ductus reuniens or in the hook portion of the cochlea or by damage to the lateral cochlear wall caused by implantation.

Rapid development of radiological equipment over the last several decades has significantly promoted the role of imaging in otology. CT and MRI have become a useful temporal bone evaluation tool. However, artifacts may limit the capability to identify some structures and its pathology [Pyykkö et al., 2019]. Thus, some recent and novel imaging methods have currently been used experimentally in temporal bone studies and these may provide additional imaging benefits in the future. Noteworthy to mention are optical coherence tomography imaging [Pitris et al., 2001], microtomography [Zou et al., 2015] and endoscopes using the coherent anti-Stokes Raman spectroscopy technique [Zou et al., 2016a] and development of advanced of contrasting agents [hou et al., 2016b]. These technological advances may provide novel means for the diagnosis and therapeutic approach of most common and important diseases affecting the inner ear.

\section{Acknowledgement}

The authors are grateful to the University of Navarra for providing research means.

\section{Disclosure Statement}

All authors declare that they have no conflict of interest.

\section{Funding Sources}

This study received no financial support.

\section{Author Contributions}

All authors contributed equally to this work: Concept - R. Manrique-Huarte, M. Manrique; Design - O. Garaycochea, M. Alvarez de Linera-Alperi; Supervision - R. Manrique-Huarte, C. Zulueta-Santos; Materials - O. Garaycochea, M. Alvarez de Linera-Alperi; Analysis and/or Interpretation - R. Manrique-Huarte, C. Zulueta-Santos; Literature Search - R. Manrique-Huarte, C. Zulueta-Santos, O. Garaycochea, M. Alvarez de Linera-Alperi, M. Manrique; Writing R. Manrique-Huarte, C. Zulueta-Santos, O. Garaycochea, M. Alvarez de Linera-Alperi, M. Manrique; Critical Reviews - M. Manrique.
48

Audiol Neurotol 2020;25:42-49 DOI: $10.1159 / 000504594$
Manrique-Huarte et al. 


\section{References}

Ash LM, Ibrahim M, Schipper MJ, Mukherji SK. The utricular macula: qualitative and quantitative analysis using 3-T imaging. J Comput Assist Tomogr. 2010 Jan;34(1):93-7.

Boutros PJ, Valentin NS, Hageman KN, Dai C, Roberts D, Della Santina CC. Nonhuman primate vestibuloocular reflex responses to prosthetic vestibular stimulation are robust to pulse timing errors caused by temporal discretization. J Neurophysiol. 2019 Jun;121(6): 2256-66.

Cajal SR. Textura del sistema nervioso del hombre y de los vertebrados: estudios sobre el plan estructural y composición histológica de los centros nerviosos adicionados de consideraciones fisiológicas fundadas en los nuevos descubrimientos. Madrid: Moya; 1899b, 1904.

Conte G, Caschera L, Tuscano B, Piergallini L, Barozzi S, Di Berardino F, et al. Three-Tesla magnetic resonance imaging of the vestibular endolymphatic space: A systematic qualitative description in healthy ears. Eur J Radiol. 2018 Dec;109:77-82.

Curthoys I, Uzun-Coruhlu H, Wong C, Jones A, Bradshaw A. The configuration and attachment of the utricular and saccular maculae to the temporal bone. New evidence from microtomography-CT studies of the membranous labyrinth. Ann N Y Acad Sci. 2009; 1164(1):13-8.

Golub JS, Ling L, Nie K, Nowack A, Shepherd SJ, Bierer SM, et al. Prosthetic implantation of the human vestibular system. Otol Neurotol. 2014 Jan;35(1):136-47.

Handzel O, Burgess BJ, Nadol JB Jr. Histopathology of the peripheral vestibular system after cochlear implantation in the human. Otol Neurotol. 2006 Jan;27(1):57-64.

Inui $\mathrm{H}$, Sakamoto T, Ito T, Kitahara T. Magnetic resonance volumetric measurement of endolymphatic space in patients without vertiginous or cochlear symptoms. Acta Otolaryngol. 2016 Dec;136(12):1206-12.

Ishiyama A, Lopez I, Ishiyama G, Tang Y. Unbiased quantification of the microdissected human Scarpa's ganglion neurons. Laryngoscope. 2004 Aug;114(8):1496-9.
Lane JI, Witte RJ, Bolster B, Bernstein MA, Johnson K, Morris J. State of the art: 3 T imaging of the membranous labyrinth. AJNR Am J Neuroradiol. 2008 Sep;29(8):1436-40.

Lorente de Nó R. Vestibulo-ocular reflex arc. Arch Neurol Psychiatry. 1933;30(2):245-91.

Merchant SN. A method for quantitative assessment of vestibular otopathology. Laryngoscope. 1999 Oct;109(10):1560-9.

Monsanto RD, Pauna HF, Kwon G, Schachern PA, Tsuprun V, Paparella MM, et al. A threedimensional analysis of the endolymph drainage system in Ménière disease. Laryngoscope. 2017 May; 127(5):E170-5.

Mukherjee P, Cheng K, Curthoys I. Three-dimensional study of vestibular anatomy as it relates to the stapes footplate and its clinical implications: an augmented reality development. J Laryngol Otol. 2019 Mar;133(3):187-91.

Mukherjee P, Uzun-Coruhlu H, Curthoys IS, Jones AS, Bradshaw AP, Pohl DV. Three-dimensional analysis of the vestibular end organs in relation to the stapes footplate and piston placement. Otol Neurotol. 2011 Apr; 32(3):367-72.

Nakashima T, Naganawa S, Sugiura M, Teranishi $\mathrm{M}$, Sone $\mathrm{M}$, Hayashi $\mathrm{H}$, et al. Visualization of endolymphatic hydrops in patients with Meniere's disease. Laryngoscope. 2007 Mar; 117(3):415-20.

Pauw BK, Pollak AM, Fisch U. Utricle, saccule, and cochlear duct in relation to stapedotomy. A histologic human temporal bone study. Ann Otol Rhinol Laryngol. 1991 Dec;100(12): 966-70.

Pelizzone M, Perez-Fornos A, Guinandi N, Van de Berg R, Kos I, Stokroos R, et al. First functional rehabilitation via vestibular implants. Cochlear Implants Int. 2014 May;15 Suppl 1:S62-4.

Pitris C, Saunders KT, Fujimoto JG, Brezinski ME. High-resolution imaging of the middle ear with optical coherence tomography: a feasibility study. Arch Otolaryngol Head Neck Surg. 2001 Jun;127(6):637-42.
Pyykkö I, Zou J, Gürkov R, Naganawa S, Nakashima T: Imaging of temporal bone. Adv Otorhinolaryngol. 2019;82:12-31.

Rask-Andersen H, Schart-Morén N, Strömbäck $\mathrm{K}$, Linthicum F, Li H. Special anatomic considerations in otosclerosis surgery. Otolaryngol Clin North Am. 2018 Apr;51(2):357-74.

Rauch SD. Vestibular histopathology of the human temporal bone. What can we learn? Ann N Y Acad Sci. 2001 Oct;942(1):25-33.

Rosenhall U. Vestibular macular mapping in man. Ann Otol Rhinol Laryngol. 1972 Jun; 81(3):339-51.

Schuknecht HF. Pathology of the Ear. 2nd ed. Philadelphia (PA): Lea \& Febiger; 1993.

Uzun-Coruhlu H, Curthoys IS, Jones AS. Attachment of the utricular and saccular maculae to the temporal bone. Hear Res. 2007 Nov; 233(1-2):77-85.

Yamane H, Iguchi H, Konishi K, Sakamaoto H, Wada T, Fujioka T, et al. Three-dimensional cone beam computed tomography imaging of the membranous labyrinth in patients with Meniere's disease. Acta Otolaryngol. 2014 Oct;134(10):1016-21.

Yamane H, Konishi K, Sakamaoto H, Yamamoto $\mathrm{H}$, Matsushita N, Oishi M, et al. Practical 3DCT imaging of the vestibular aqueduct for Meniere's disease. Acta Otolaryngol. 2015 Aug;135(8):799-806.

Zou J, Isomäki A, Hirvonen T, Aarnisalo A, Jero J, Pyykkö I. Label-free visualization of cholesteatoma in the mastoid and tympanic membrane using CARS microscopy. J Otol. 2016a Sep;11(3):127-33.

Zou J, Lähelmä J, Koivisto J, Dhanasingh A, Jolly C, Aarnisalo A, et al. Imaging cochlear implantation with round window insertion in human temporal bones and cochlear morphological variation using high-resolution cone beam CT. Acta Otolaryngol. 2015 May; 135(5):466-72.

Zou J, Pyykkö I, Hyttinen J. Inner ear barriers to nanomedicine-augmented drug delivery and imaging. J Otol. 2016b Dec;11(4):165-77. 